\title{
Unrecognized diabetes in critically ill COVID-19 patients
}

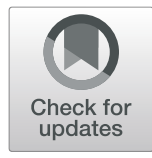

Sebastian J. Klein ${ }^{1}$, Dietmar Fries ${ }^{2}$, Susanne Kaser ${ }^{3}$, Simon Mathis ${ }^{4}$, Claudius Thomé ${ }^{5}$ and Michael Joannidis ${ }^{*^{*}}$ (D)

Dear Editor,

Since the first discovery of severe acute respiratory syndrome coronavirus 2 (SARS-CoV-2) and description of the coronavirus disease 2019 (COVID-19), a pandemic has evolved. Due to winter tourism, Tyrol, a federal province of Austria with 750,000 inhabitants, has emerged as an epicenter in Austria being faced with a surge of critically ill COVID-19 patients reaching its peak on April 8, 2020.

We retrospectively analyzed the incidence of diabetes in all critically ill patients admitted to the four dedicated COVID-19 intensive care units (ICU) at the University Hospital in Innsbruck, Tyrol, Austria, which covers 180,000 inhabitants as primary hospital and also functions as a tertiary referral center for the whole region of Tyrol. Patients were included in the analysis if they were 18 years of age or older, had confirmed COVID-19, and were admitted to an intensive care unit from March 11 to April 29, 2020. COVID-19 was confirmed by reverse-transcriptasepolymerase-chain-reaction assays of nasopharyngeal swab specimens. Data were abstracted manually from electronic and paper-based health records. Glycated hemoglobin (HbA1c) was measured on admission by high-performance liquid chromatography (HPLC-UV/ VIS).

Of 47 COVID-19 patients admitted to our ICUs, HbA1c was measured in 44, which were included in the analysis (Table 1). The median age of patients was 61.5 (IQR 53.0-68.0). Thirty-five (80\%) patients required invasive mechanical ventilation (IMV). Additionally, 4 patients (9\%) required veno-venous extracorporeal membrane oxygenation (vvECMO). At the time of writing this article, 11 patients $(25 \%)$ have died in the hospital, 25 (56.8\%) have been discharged alive from the ICU, 20 patients (45.5\%) were discharged alive from the hospital, and 13 patients (29.5\%) are still hospitalized.

Median HbA1c was 6.5\% (IQR 6.1-6.7\%). When categorizing patients according to HbA1c [1], 24 (54.5\%) were considered to have diabetes mellitus (HbA1c $\geq 6.5 \%), 16$ (36.3\%) were considered to have prediabetes $(\mathrm{HbA} 1 \mathrm{c} \geq 5.7 \%<6.5 \%)$, and only $4(9 \%)$ had no diabetes $(\mathrm{HbA} 1 \mathrm{c}<5.7 \%)$. Interestingly, only 7 (15.9\%) patients showed a medical history of diabetes mellitus. Five (11.4\%) patients had previously been treated with antidiabetic medication, and no patient had required insulin prior to hospitalization. Patients with increased $\mathrm{HbA1c}$ levels developed higher maximum CRP and IL-6 levels during their ICU stay. There was a trend to higher in-hospital mortality with increasing HbA1c.

The median body mass index (BMI) was $29.4 \mathrm{~kg} / \mathrm{m}^{2}$ (IQR 26.2-32.7), which is slightly higher than a previously studied sample of critically ill patients in Austria [2], with a median BMI of $26 \mathrm{~kg} / \mathrm{m}^{2}$. BMI did not differ significantly between diabetic and non-diabetic patients (Fig. 1).

In conclusion, $85 \%$ of COVID-19 treated in our intensive care units had prediabetes and diabetes which appear to be predisposing factors for severe manifestations of COVID-19, potentially impairing outcome. This is in line with previous observations from the first SARS-CoV epidemic [3].

\footnotetext{
* Correspondence: michael.joannidis@i-med.ac.at

'Division of Intensive Care and Emergency Medicine, Department of Internal Medicine, Medical University Innsbruck, Anichstrasse 35, 6020 Innsbruck, Austria

Full list of author information is available at the end of the article
} 
Table 1 Characteristics of included patients, stratified by $\mathrm{HbA} 1 \mathrm{C}$

\begin{tabular}{|c|c|c|c|c|}
\hline Characteristic & Total $(\boldsymbol{N}=44)$ & $\mathrm{HbA} 1 \mathrm{c}<5.7 \%(\boldsymbol{N}=4)$ & $\mathrm{HbA} 1 \mathrm{c} \geq 5.7<6.5 \%(\boldsymbol{N}=16)$ & $\mathrm{HbA1c} \geq 6.5 \%(\boldsymbol{N}=24)$ \\
\hline Age—median (IQR) [years] & $61.5(53.0-68.0)$ & $53.5(43.8-64.0)$ & $64(53.8-68.0)$ & $59(53.8-69.8)$ \\
\hline Male sex-no. (\%) & $32(72)$ & $3(75)$ & $13(81)$ & $16(66)$ \\
\hline Caucasian race-no. (\%) & $32(72)$ & $3(75)$ & $13(81)$ & $16(66)$ \\
\hline BMI-median (IQR) $\left[\mathrm{kg} / \mathrm{m}^{2}\right]$ & $29.4(26.2-32.7)$ & $27.8(24.9-30.6)$ & $27.7(25.5-34.8)$ & $29.5(26.9-32.6)$ \\
\hline $\mathrm{HbA} 1 \mathrm{c}$-median (IQR) [\%] & $6.5(6.1-6.7)$ & $5.6(5.5-5.6)$ & $6.2(5.9-6.3)$ & $6.7(6.6-7.1)$ \\
\hline $\begin{array}{l}\text { Maximum CRP_median } \\
\text { (IQR) [mg/dl] }\end{array}$ & $31.5[20.5-35.5]$ & 18.3 [16.9-20.9] & $29.8[19.7-35.9]$ & $33.0[22.4-35.8]$ \\
\hline $\begin{array}{l}\text { Maximum IL-6-median } \\
\text { (IQR) [ng/l] }\end{array}$ & 797.9 [381.7-1886.3] & $284.9[212.2-383.2]$ & $1097.4[403.8-2200.3]$ & 851.9 [419.3-2156.3] \\
\hline \multicolumn{5}{|l|}{ Known comorbidity*_-no. (\%) } \\
\hline Metabolic syndrome & $8(18)$ & $0(0.0)$ & $4(25)$ & $4(17)$ \\
\hline Prediabetes & $0(0)$ & $0(0)$ & $0(0)$ & $0(0)$ \\
\hline Diabetes mellitus type I & $0(0)$ & $0(0)$ & $0(0)$ & $0(0)$ \\
\hline Diabetes mellitus type II & $7(15)$ & $1(25)$ & $0(0)$ & $6(25)$ \\
\hline Cardiovascular & $11(25)$ & $2(50)$ & $2(13)$ & $7(29)$ \\
\hline Hypertension & $19(43)$ & $2(50)$ & $7(44)$ & $10(42)$ \\
\hline Renal & $6(13)$ & $0(0)$ & $3(19)$ & $3(13)$ \\
\hline Liver & $4(9)$ & $0(0)$ & $2(13)$ & $2(8)$ \\
\hline Metastatic disease & $0(0)$ & $0(0)$ & $0(0)$ & $0(0)$ \\
\hline Hematological malignancy & $2(4)$ & $0(0)$ & $2(13)$ & $0(0)$ \\
\hline $\begin{array}{l}\text { Non-hematological } \\
\text { malignancy }\end{array}$ & $3(7)$ & $1(25)$ & $2(13)$ & $0(0)$ \\
\hline Immunosuppression & $5(11)$ & $0(0)$ & $3(19)$ & $2(8)$ \\
\hline COPD & $6(13)$ & $0(0)$ & $2(13)$ & $4(17)$ \\
\hline Asthma & $4(9)$ & $1(25)$ & $2(13)$ & $1(4)$ \\
\hline Respiratory disease_-others & $4(9)$ & $1(25)$ & $3(19)$ & $0(0)$ \\
\hline Neurologic comorbidity & $3(7)$ & $1(25)$ & $2(13)$ & $0(0)$ \\
\hline $\begin{array}{l}\text { Chest radiographic findings } \\
\text { consistent } \\
\text { with viral pneumonia—no. (\%) }\end{array}$ & $43(98)$ & $4(100)$ & $16(100)$ & $23(96)$ \\
\hline SARS-CoV-2-PCR positive-no. (\%) & $44(100)$ & $4(100)$ & $16(100)$ & $24(100)$ \\
\hline $\begin{array}{l}\text { Invasive mechanical } \\
\text { ventilation—no. (\%) }\end{array}$ & $35(80)$ & $2(50)$ & $13(81)$ & $20(84)$ \\
\hline $\begin{array}{l}\text { Veno-venous extracorporeal } \\
\text { membrane } \\
\text { oxygenation-no. (\%) }\end{array}$ & $4(9)$ & $1(25)$ & $1(6)$ & $2(8)$ \\
\hline Death in hospital—no. (\%) & $11(25)$ & $0(0)$ & $4(25)$ & $7(29)$ \\
\hline
\end{tabular}

Abbreviations: IQR interquartile range, $B M I$ body mass index, HbA1c glycated hemoglobin, CRP C-reactive protein, IL-6 interleukin-6, COPD chronic obstructive pulmonary disease, SARS-CoV-2 severe acute respiratory syndrome coronavirus 2

*If specified in the patients' health records

Hyperglycemia may alter the response of the innate immune system through several mechanisms. It may induce Toll-like receptor expression and inhibit neutrophil function, decrease vascular dilation, and increase permeability [4]. Furthermore, it can cause direct glycosylation of proteins, thereby altering the structure of complement, and may cause a cytokine storm $[4,5]$. Recent data demonstrating viral particles in endothelial cells of several organs suggest "endotheliitis" as a possible mechanism of organ dysfunction leading to critical illness in COVID-19 patients which may be aggravated by endothelial 


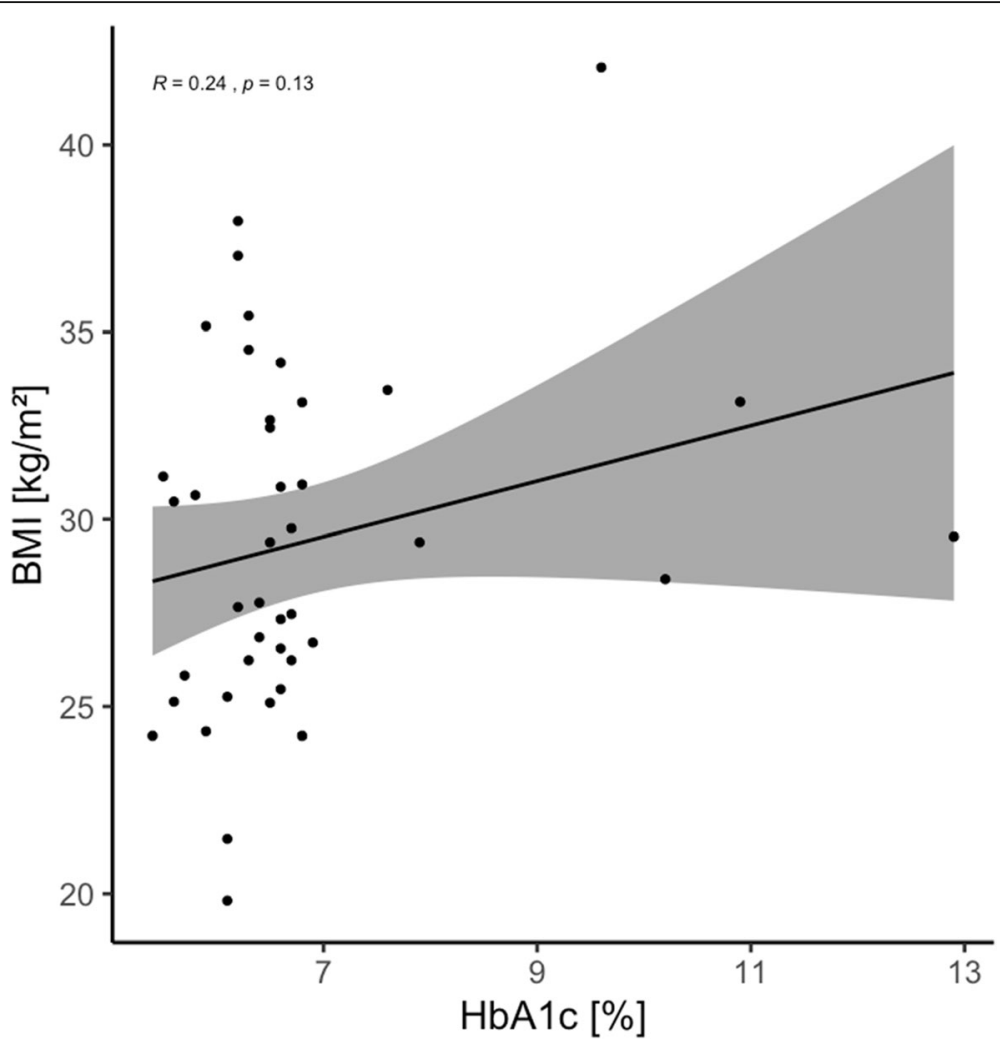

Fig. 1 Correlation between body mass index (BMI) $\left[\mathrm{kg} / \mathrm{m}^{2}\right]$ and glycated hemoglobin ( $\left.\mathrm{HbA} 1 \mathrm{c}\right)[\%]$

dysfunction associated with prediabetes and diabetes [6]. More pronounced peak levels of inflammation observed in our patients with abnormal HbA1c may support such an assumption. In conclusion, we recommend routine measurement of HbA1c in hospitalized COVID-19 patients for additional risk stratification, because most patients of our cohort were previously not diagnosed with having impaired glucose tolerance.

\section{Acknowledgements}

We would like to thank Romuald Bellmann, Robert Breitkopf, Christoph Hochhold, Andreas Peer, Christian Preuß Hernández, and Mathias Ströhle for their support in conducting this analysis.

\section{Authors' contributions}

SJK, SK, and MJ collected data and wrote the manuscript. DF, SM, and CT collected data for this study. The author(s) read and approved the final manuscript.

\section{Funding}

No funding was received for this study.

\section{Availability of data and materials}

No data is publicly available at this time.

\section{Ethics approval and consent to participate}

This study was approved by the ethics committee of the Medical University Innsbruck (\# 1099/2020).

\section{Consent for publication}

Not applicable — the manuscript contains no individual patient data.

\section{Competing interests}

None of the authors have any conflicts of interest to declare.

\section{Author details}

${ }^{1}$ Division of Intensive Care and Emergency Medicine, Department of Internal Medicine, Medical University Innsbruck, Anichstrasse 35, 6020 Innsbruck, Austria. ${ }^{2}$ Department of General and Surgical Intensive Care Medicine, Medical University Innsbruck, Innsbruck, Austria. ${ }^{3}$ Department of Internal Medicine I \& CD laboratory for metabolic cross-talk, Medical University Innsbruck, Innsbruck, Austria. ${ }^{4}$ Department of Anesthesia and Critical Care Medicine, Medical University Innsbruck, Innsbruck, Austria. ${ }^{5}$ Department of Neurosurgery, Medical University Innsbruck, Innsbruck, Austria.

Received: 11 June 2020 Accepted: 1 July 2020

Published online: 09 July 2020

\section{References}

1. World Health Organization. Use of glycated haemoglobin (HbA1c) in diagnosis of diabetes mellitus: abbreviated report of a WHO consultation. https://www.who.int/cardiovascular_diseases/report-hba1 C_2011_edited.pdf. Published 2011. Accessed 04 May 2020.

2. Roth D, Meyer L, Bickell F, et al. P002 - Atemwegsmanagement an einer von Internisten geführten Notaufnahme. Medizinische Klinik - Intensivmedizin und Notfallmedizin. 2012;107:301-40.

3. Yang JK, Feng Y, Yuan MY, et al. Plasma glucose levels and diabetes are independent predictors for mortality and morbidity in patients with SARS. Diabet Med. 2006;23(6):623-8.

4. Jafar $\mathrm{N}$, Edriss $\mathrm{H}$, Nugent $\mathrm{K}$. The effect of short-term hyperglycemia on the innate immune system. Am J Med Sci. 2016;351(2):201-11. 
5. Wang Q, Fang P, He R, et al. O-GlcNAc transferase promotes influenza A virus-induced cytokine storm by targeting interferon regulatory factor-5. Sci Adv. 2020;6(16):eaaz7086.

6. Varga Z, Flammer AJ, Steiger $P$, et al. Endothelial cell infection and endotheliitis in COVID-19. Lancet. 2020;395(10234):1417-8.

\section{Publisher's Note}

Springer Nature remains neutral with regard to jurisdictional claims in published maps and institutional affiliations.

Ready to submit your research? Choose BMC and benefit from:

- fast, convenient online submission

- thorough peer review by experienced researchers in your field

- rapid publication on acceptance

- support for research data, including large and complex data types

- gold Open Access which fosters wider collaboration and increased citations

- maximum visibility for your research: over $100 \mathrm{M}$ website views per year

At $B M C$, research is always in progress.

Learn more biomedcentral.com/submissions 